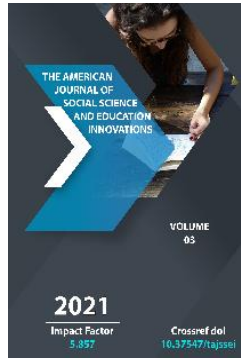

\title{
Ideological And Artistic Features Of Shukur Kholmirzaev's Works
}

\author{
Hamidova Muhayoxon Obidovna \\ Candidate Of Philological Sciences, Associate Professor, Namangan State University, Uzbekistan
}

Journal Website:

http://usajournalshub.c

om/index,php/tajssei

Copyright: Original content from this work may be used under the terms of the creative commons attributes 4.0 licence.

\section{ABSTRACT}

Shukur Kholmirzaev, as a master of his own artistic style, avoids criticism, one-sidedness, narrative. Including "Essiz, Eshniyoz!" through the depiction of the protagonist of the story Eshniyaz, the changes in the protagonist's worldview, the protagonist's tragedy are illuminated in all respects on the basis of the requirements of broad and detailed brutal realism.

\section{KEYWORDS}

Artistic style, artistic intention, creative process, art, writing skills, the role of word art, artistic means, criticism, narrative, heroic worldview, life process, analysis, national, spiritual and cultural values, new perspective, deep observation, artistic means, "exaggerating the good and hiding the bad", the image of Eshniyaz, ruthless realism.

\section{INTRODUCTION}

30 years have passed since the independence of the Republic of Uzbekistan. Thanks to independence, great attention has been paid to the study of our rich literary and spiritual heritage. One of the urgent tasks is to cover the ideological and artistic features of the 
works of Shukur Kholmirzaev, one of the most worthy writers in Uzbek prose.

The writer, who describes our life in the 70s, draws a bitter but true conclusion: our society is nearing its final stop. Continuation-crisis. The road seems inevitable. Only a new, trustworthy, strong, free and honest, purposeful path that does not look at the heart of another can lead a person to the destination without hurting his heart.

In our view, the concepts of skill and courage in his work are so intertwined that it is even difficult to distinguish which of these two qualities leads. "Essiz, Eshniyaz!" (1987-1988).

The protagonists of the author's novel "Make a Bridge" and the drama "Black Belt" were created using the method of depiction "exaggerating the good and hiding the bad", which is one of the artistic means of independence, "Essiz, Eshniyaz!" The image of Eshniyaz in the story was created on the basis of the requirements of ruthless realism.

As the literary scholar Sh. Daniyarova points out, we see in his (Shukur Kholmirzaev's - M.H.) style the positive influence of Western literature and art, in particular, "ruthless realism" in Italian cinema. His realism is devoid of luxury and airiness. On the contrary, it has a strong artistic flair."

Such ruthless realism reigns from the beginning to the end of the story.

If in order to create the image of national heroes in the novel "The Bridge" and the drama "Black Belt" the author created a whole system of artistic means, typical of the works of independence, "Essiz, Eshniyaz!" does not use any of these artistic means in his story. On the contrary, social realism adheres strictly to the rules. Nevertheless, "Essiz, Eshniyaz!" The story can be called a work of independence.

The logical question arises as to how seemingly contradictory concepts, such as the method of socialist realism and the work of independence, serve together in the realization of the author's creative goal. This question cannot be answered in a single sentence. We will therefore try to address this issue gradually in the analysis process. There are specific reasons for this.

First of all, the events in the novel "Make a Bridge" and the drama "Black Belt" were dedicated to the life of the independence camp, "Essiz, Eshniyaz!" his story is devoted to depicting the life of a young socialist system, standing on the side of the revolutionaries.

Second, the concept of socialist realism also means the depiction of socialist life in a realistic way.

Third, while the previous two plays are intended to describe the activities of the leading leaders of the independence movement, the story aims to portray the warlike and tragic fate of the Red Commander Eshniyaz, who fought valiantly to end those independenceists.

To achieve this artistic goal, the author portrays the protagonist Eshniyaz as a person who consistently adheres to the rules of the new system, acts within the rules and is a selfless soldier of the Soviet regime.

The rules of the new system were not in practice, but on paper to protect the interests of the local people. 
The main contradiction arises between these populist principles of the new system and the actions of officials at different levels of power. In other words, the more beautiful the laws of the Soviet state were filled with promises, the harder it was to implement them.

Different categories of officials in power in the Soviet Union were forced to violate state laws at every step in their own interests. In other words, Soviet state officials were virtually disobedient to the rules of government.

As this situation prevailed in all regions of the Soviet state, a common moral and ethical norm began to form among the country's leadership and officials. This norm is hypocrisy, that is, "The word is different, the deed is different!", "On paper it is different, in practice it is different!" was a perverted spiritual-moral norm.

The norm of hypocrisy was approved by all high-ranking officials in the Soviet state.

Thus, hypocrisy has become one of the main attributes (signs) of public policy. This attribute was formed in the 1920 s and began to apply in all spheres of life in the country.

Throughout his life, Eshniyaz, who relied on practical factors such as honest work, the struggle for the interests of the people, and sincere service to the Soviet government, faced opposition to this policy of hypocrisy.

"Essiz, Eshniyoz!" the main conflict of the story is also based on the struggle between Eshniyaz and the policy of hypocrisy, whose whole life was devoted to honest labor, justice, and devotion to public affairs.
The story begins with an artistic depiction of the place where Eshniyaz was born and raised:

"On the northeast side of Boysun, in the foothills of the lowlands, is the village of Koshbulak. The people who lived there - mostly barbarians and whites - called the Uzbek-bell seed "holes", and the word "worthy" of the name and body was said to them. The guys are stubborn, one-word; moreover, the rider, the sniper - in this respect Boysun was ahead of the boys."

After this information, the writer introduces the reader to the villagers, their profession, the family situation of the protagonist Eshniyaz.

"The richest man in Koshbulak was Mamarajab Jebachi, who had three wives, more than a thousand cattle and sheep, and many servants. One of the servants of this rich man was Yunus obkash, who carried water from the river to the houses of the rich people in the ovens loaded on two donkeys from morning till night.

A second son was born in the cage of this obkash. The boy's head was as big as a palm, and his eyes were wide.

On the day of her chill, her grandmother Jangil said, "There is nori, it will be special. May this need be fulfilled for the rest of your life, "said Eshniyaz.

Eshniyoz, as it is told in fairy tales, was a young man in the blink of an eye: a ten-year-old boy, three or four years older than him, struggled like his brother; If he runs like that, the dog will not give him a handle like a landing wheel, and he will crawl under the horses again."

When Eshniyaz was sixteen years old, his father died suddenly and he was hired to shepherd 
Mamarajabboy on the condition that he get one sheep a year.

"The rain of 1915 is in the history of Boysun ...

One-third of Eshniyaz's flock was also fed.

When the rich man, with his eyes full and his turban on, whipped all his shepherds, he came to Eshniyaz:

"Go!" I have no right! The floodwaters have receded! he said.

Eshniyaz lost ten sheep and returned to the cage.

Thus, Eshniyaz was the first to face social injustice. This, in turn, paved the way for the development of Eshniyaz's future career.

"Eshniyaz has now started guarding the palace and the madrassa in the city. But Khojamshukur Tuqsabo was more valued for his bravery and riding than for his guarding. He always took her with him to weddings, gave her a beloved black horse, put it on a mule, wrestled with great wrestlers, and Eshniyaz's "shoulders were not strong" in wrestling.

Meanwhile, Mamarajab Jebachi, the elder of Koshbulak, dies. He will be replaced by Eshniyaz as an elder. From this day, the sociopolitical activity of Eshniyaz will begin.

The Red Army, pursuing Amir Alimkhan, who had passed through Boysun to Babatag, captured Boysun. But they won't stay in Boys for long. Because they are few in number, they go back to join the main army.

Knowing that the Red Army would return again, the local people revolted. But they cannot resist a regular army equipped with modern weapons.

"The Red Army, called from Russia, or rather from Bukhara, chasing the Emir, consisted of 5 brigades, a total of 6,000 fighters. Among them were 3 brigades - archers, 2 cavalry, called "Gissar Expeditionary Corps", led by Marsov.

The rebels are defeated. Eshniyaz's valinemati Khojamshukur tugsabo and other great men of the land are captured. Eshniyaz, who saw his pir among his captured compatriots, loses himself.

"Pirim, how's the paint now?" said Eshniyaz.

"Oh, my gosh ..." said the headless bitch. His hand was folded back and tied with a turban. Then his eyes filled with tears and he looked at the qibla. "The world is lost!"

Eshniyaz is upset."

So, Eshniyaz understood the situation and, according to Piri, entered the service of the Soviet government only after a meeting with the Emergency Commission - Chairman of the Cheka - Geyser.

Thus, the fate of Eshniyaz, who believed that the Soviet government would act with nationalism and justice, and served him faithfully in this way, ends as follows:

When the issue of digging the Kumkurgan canal was raised, Eshniyaz, who had voluntarily gone to the canal along with others, would not return. Only about him, "Eshniyaz is the ENEMY OF THE PEOPLE." He is sentenced to be shot first. But the Supreme Court under the Central Asian Politburo will replace the death penalty with 10 years in prison. Thus, his selfless service 
is rewarded by the surplus of the Soviet government. The people branded him an enemy and sent him into exile, along with the captives.

So, it is common in the Soviet era to end a person's life tragically and acquit him 44 years later.

"Essiz, Eshniyoz!" in contrast to the previous two works in the story, the aim is to shed light on the life of the Soviets. As in the previous two works, no artistic methods were used to express the ideas of independence.

"Essiz, Eshniyoz!" - realistic work. It was written in full accordance with the method of social realism, which was in accordance with the wishes of the Soviets. The protagonist acts in full compliance with the rules of the socialist system. Eshniyaz's work is an example for the builders of socialism.

Nevertheless, Eshniyaz is repressed as an enemy of the people. He dies as a national hero. The oppressors will be destroyed, not by an arrow, but by a system that has served them wholeheartedly - the Soviet system.

The story is written in a style that fully meets the requirements of the creative method of social realism, in contrast to the author's novel "The Bridge" and the drama "Black Belt".

In general, a writer notices events that no one notices or notices because of his or her subtle emotion and sensitivity, and is able to convey these in his or her works in a more interesting and impressive way to the reader.

\section{REFERENCES}

1. Boltaboev H. Prose and style.- Tashkent: Science, 1992.- B. 4.

2. Boqiy N. Find a base point! // Vatan, 1994.13 September.

3. Vladimirova N. Ideas and images in Uzbek stories. -Tashkent: Fan, 1969.- B. 30.

4. Mahmudov M. Philosophy of talent and creativity.- Tashkent: Literature and art, 1976.- B. 70-71.

5. Kholmirzaev Sh., Usmonov T. Avalanche.- T .: Young Guard, 1990.

6. Normatov U. Horizons of our prose.Tashkent: Literature and art, 1974.- B. 98.

7. Rustamova I. The problem of pride in Uzbek dramaturgy (70-80s). Fil.fan.nom.avtorefera. -Tashkent, 1999, B. 13

8. Sulton I. A word on the threshold // Literature and art of Uzbekistan, 1990.December 21.

9. Rahimjanovna S. M. Teaching ethics to students in technology education //Asian Journal of Multidimensional Research (AJMR). - 2020. - T. 9. - №. 3. - C. 119-122.

10. Inomidinova D. I. Impact of learning foreign languages on children development //Middle European Scientific Bulletin. 2021. - T. 8.

11. Rahimjanovna S. M. The professional skill and competence of modern educatorpedagogue //European Journal of Research and Reflection in Educational Sciences Vol. - 2019. - T. 7. - №. 12.

12. Madinabonu Abdumannob kizi Yusufjonova. (2021). A Household Tale in Korean Folklore. INTERNATIONAL JOURNAL OF DISCOURSE ON INNOVATION, INTEGRATION AND EDUCATION, 2(2), 259-263. Retrieved from http://www.summusjournals.uz/index.php /ijdiie/article/view/631 
13. Madinabonu Yusufjonova "Analysis of a Korean Household Fairy Tale" Published in International Journal of Trend in Scientific Research and Development (ijtsrd), ISSN: 2456-6470, Special Issue | International Research Development and Scientific Excellence in Academic Life, March 2021, pp.128-130, URL: https://www.ijtsrd.com/papers/ijtsrd38770 .pdf

14. ЮСУФЖОНОВА M. A. K. ХУДОЖЕСТВЕННЫЕ СРЕДСТВА, ИСПОЛЬЗУЕМЫЕ В КОРЕЙСКИХ ПОСЛОВИЧНЫХ ИЗРЕЧЕНИЯХ //МОЛОДЕЖЬ И СИСТЕМНАЯ МОДЕРНИЗАЦИЯ СТРАНЫ. - 2017. - С. 5355.

15. ЮСУФЖОНОВА М. А. К. ОСОБЕННОСТИ ПЕРЕВОДА КОРЕЙСКИХ ПОСЛОВИЦ И ПОГОВОРОК //Поколение будущего: взгляд молодых ученых. - 2016. - С. 226230.

16. ЮСУФЖОНОВА М. А. СТИЛЬ АВТОРА И ЛИТЕРАТУРНОГО ПЕРЕВОДА // Молодежь и XXI век-2017. - 2017. - С. 263265.

17. Худайбергенова 3. Н. и др. "TAHGUN HAQIDA AFSONA","ONDAL","VA “QIROL KIM SURO HAQIDA AFSONA" ASARLARIDAGI IBORALARNING LEKSIKSEMANTIK XUSUSIYATLARI //Молодой исследователь: вызовы и перспективы. 2017. - C. 196-199.

18. 17. Madinabonu Yusufjonova "A FAIRY TALE AS A REFLECTION OF THE NATIONAL CULTURE OF THE PEOPLE" ACADEMICIA: An International Multidisciplinary Research Journal, https://saarj.com ISSN: 2249-7137 Vol. 11, Issue 3, March 2021, pp. 2533-2539 DOI: 10.5958/2249-7137.2021.00899.5

19. Mahfuza Rahimjanovna Shermatova "The Analysis of Examples of Classical Literature in the Primary School" Published in International Journal of Trend in Scientific Research and Development (ijtsrd), ISSN: 2456-6470, Special Issue | International Research Development and Scientific Excellence in Academic Life, March 2021, pp.137-140, URL: https://www.ijtsrd.com/papers/ijtsrd38774 .pdf

20. Yusufjonova M. ABDULLA KAHHAR AS A SKILLFUL TRANSLATOR //European Journal of Research and Reflection in Educational Sciences Vol. - 2019. - T. 7. №. 12. M Yusufjonova - European Journal of Research and Reflection in ..., 2019 idpublications.org

21. Shermatova M. R. BOSHLANG'ICH SINF O'QUVCHILARINI TEXNOLOGIYA FANIDA AMALIY ISHLAR ORQALI HAR TOMONLAMA TARBIYALASH //Интернаука. - 2019. - №. 1-2. - С. 58-59.

22. ШЕРМАТОВА М. Р. ТЕХНОЛОГИИ ДИСТАНЦИОННОГО ОБУЧЕНИЯ //ОБРАЗОВАНИЕ. НАУКА. КАРЬЕРА. 2019. - C. 93-95.

23. Шерматова М. Р. ТЕХНОЛОГИИ И ТРУД КАК ЧАСТИ ОБРАЗОВАТЕЛЬНОЙ КУЛЬТУРЫ //Педагогика и психология в современном мире: теоретические и практические исследования. - 2018. - С. 101-104.

24. Шерматова М. Р. Особенности и методики применения информационнокоммуникативных технологий для активизации учебной деятельности в образовательном процессе на уроках в начальной школе //Молодой ученый. 2017. - №. 7. - C. 509-511.

25. ШЕРМАТОВА М. Р. ПРАКТИЧЕСКИЕ МЕТОДЫ И ПРИЕМЫ РЕАЛИЗАЦИИ ИКТ АЛЯ АКТИВИЗАЦИИ УЧЕБНОЙ ДЕЯТЕЛЬНОСТИ МЛАДШИХ 
The American Journal of Social Science and Education Innovations (ISSN - 2689-100x)

Published: April 30, 2021 | Pages: 639-645

Doi : https://doi.org/10.37547/tajssei/Volume03Issue04-104

2021: 5.857

OCLC - 1121105668

ШКОЛЬНИКОВ //МОЛОДЕЖЬ И

СИСТЕМНАЯ МОДЕРНИЗАЦИЯ СТРАНЫ.

- 2017. - C. 451-454.

26. Шерматова М. Р. Межличностные взаимоотношения в преподавании технологии //Молодой ученый. - 2017. №. 43. - С. 129-131.

27. Xolmirzaev Sh. Almonds bloom in winter. Tashkent: Literature and Art, 1986. - B. 108

28. Kholmirzaev Sh., Normatov U. Problems of style, artistic form // Sharq yulduzi, 1977.- № 8.- B. 204.

29. Kochkarov R. Interpretation of three stories // Rainbow: Literary-critical annual collection. - Tashkent: Young Guard, 1989.B. 231. 